\title{
PREVENSI MISKONSEPSI SISWA PADA KONSEP REAKSI REDOKS MELALUI MODIFIED INQUIRY MODELS
}

\author{
Wahyu Juli Hastuti ${ }^{1)}$ \\ Suyono ${ }^{2)}$ \\ Sri Poedjiastoeti ${ }^{3)}$ \\ ${ }^{1)}$ SMK Negeri 1 Bontang, Kalimantan Timur \\ ${ }^{2}$ Dosen Program Studi Pendidikan Sains, Program Pascasarjana Universitas Negeri Surabaya \\ ${ }^{3}$ Dosen Program Studi Pendidikan Sains, Program Pascasarjana Universitas Negeri Surabaya \\ e-mail: wahyujulihastuti@gmail.com
}

\begin{abstract}
Abstrak: Implementasi model modified inquiry bertujuan memprevensi miskonsepsi siswa pada konsep reaksi redoks. Subjek penelitian adalah siswa kelas XIPA 3, XIPA 5, dan X IPA 7 SMA Negeri 1 Sidoarjo. Penelitian dilakukan dengan menggunakan rancangan one group pretest posttest design. Instrumen yang digunakan adalah three-tier diagnostic test untuk menentukan miskonsepsi siswa. Data diskrit dianalisis secara deskriptif, sedangkan data ordinal, dan interval dianalisis secara inferensial. Hasil penelitian menunjukkan pembelajaran dengan menggunakan model modified inquiry telah berhasil memprevensi miskonsepsi siswa sebanyak 60\% (X IPA 3), 48\% (X IPA 5), 64\% (X IPA 7), dan telah meningkatkan hasil belajar secara signifikan meskipun masih memerlukan pembelajaran remedial.
\end{abstract}

Kata Kunci: prevensi, miskonsepsi, reaksi redoks, modified inquiry.

Abstract: Implementation of a Modified Inquiry Model for is prevent students' misconceptions on Redox Reactions. Research participants were students of Science Class at grade X at SMAN 1 Sidoarjo. This study was conducted using One Group Pretest and Posttest research design. The instrument used is Three-tier Diagnostic Test to determine of students' misconceptions. Discreate data was descriptively analyzed while ordinal and interval data was inferentially analyzed. Findings of this study show that learning process using Modified Inquiry could successfully prevent 60\% (X IPA 3), 48\% (X IPA 5), 64\% (XIPA 7), student's misconceptions and increase student's learning achievement significantly, but still require remedial learning.

Keywords: prevention, misconception, redox reaction, modified inquiry.

\section{PENDAHULUAN}

Harapan peneliti sebagai seorang guru adalah siswa mampu memahami, menerapkan, dan menganalisis pengetahuan faktual, konseptual, prosedural berdasarkan rasa ingin tahunya tentang ilmu kimia, penyebab fenomena dan kejadian, serta siswa mampu menerapkan pengetahuan prosedural pada ilmu kimia untuk memecahkan masalah. Harapan tersebut dapat tercapai apabila guru dalam proses belajar mengajar menggunakan metode, model maupun strategi yang berbasis penyingkapan (discovery) atau penelitian (inquiry) (Kementerian Pendidikan dan Kebudayaan, 2013).

Menurut Wenning (2012) discovery dan inquiry merupakan bagian dari Level of Inquiry Model of Science Teaching, yaitu serangkaian siklus pembelajaran dalam konteks siklus besar yang mencakup berbagai tingkat penelitian. Inkuiri mendorong siswa untuk berpikir keras, yaitu guru mendorong siswa untuk bertindak seperti ilmuwan dalam setting eksperimen yang lebih formal untuk menentukan suatu sistem. Siswa dilatih mengkonstruksi sendiri konsep-konsep kimia dalam pemikirannya, melalui pembelajaran berbasis penelitian atau inkuiri. Siswa tidak dapat memahami konsep-konsep kimia, apabila siswa tidak dapat mengkonstruksinya secara benar, atau bahkan siswa mengalami miskonsepsi.
Kenyataan adanya miskonsepsi pada siswa, telah dibuktikan dalam banyak penelitian antara lain Horton (2004), Wahyuningrum dan Suyono (2013), serta Yunianingsih dan Suyono (2013). Horton (2004) mengungkapkan miskonsepsi siswa hampir terjadi pada setiap konsep dalam kimia, yaitu struktur atom, stokiometri, larutan, reaksi kimia, energi dalam reaksi kimia, kesetimbangan kimia, pembakaran, reaksi asam basa, reaksi oksidasi-reduksi (redoks), elektrokimia, model molekul, termodinamika dan ikatan kimia. Wahyuningrum dan Suyono (2013) mengungkapkan bahwa miskonsepsi siswa pada konsep struktur atom berhasil diprevensi dengan strategi Process Oriented Guided Inquiry Learning (POGIL), meskipun masih menyisakan miskonsepsi sebanyak $24,24 \%$. Penelitian Yunianingsih dan Suyono (2013) mengungkapkan miskonsepsi siswa pada konsep ikatan kimia yang berhasil diprevensi dengan strategi POGIL, namun masih ditemukan miskonsepsi siswa sebanyak $44 \%$. Berdasarkan hasil penelitian tersebut, dapat ditarik simpulan bahwa miskonsepsi siswa dapat terjadi dalam mata pelajaran kimia.

Mata pelajaran kimia di kelas X SMA/MA merupakan kelanjutan materi kimia yang terintregrasi dalam mata pelajaran IPA di SMP/MTs yang terdiri dari 4 kompetensi inti. Khusus untuk kompetensi inti yang berorientasi pada pengetahuan, terdiri dari 11 kompetensi dasar (Kementerian Pendidikan dan 
Kebudayaan, 2013). Menurut Horton (2004), Chiu (2005), Reid (2008), Barke (2012), dan Al-Balushi et al. (2012), salah satu kompetensi dasar yang sulit pada mata pelajaran kimia SMA adalah menganalisis perkembangan konsep reaksi oksidasi-reduksi serta menentukan bilangan oksidasi atom dalam molekul atau ion, sehingga dimungkinkan terjadi miskonsepsi pada konsep reaksi redoks.

Prevensi miskonsepsi siswa pada konsep reaksi redoks, dilaksanakan dengan menggunakan inkuiri seperti yang disarankan oleh Kementerian Pendidikan Nasional dan Kebudayaan dalam Kurikulum 2013. Menurut Brown et al. (dalam Opara and Oguzor, 2011) model pembelajaran dalam bidang science dengan menggunakan inkuiri, dibedakan menjadi tiga yaitu free inquiry, modified inquiry dan guided inquiry.

Kelemahan model pembelajaran guided inquiry adalah kurang berhasil dalam kelas besar, karena sebagian waktu hilang untuk membantu siswa menemukan teori-teori atau siswa menunggu giliran untuk memperoleh bantuan guru (Sund and Trowbridge,1973). Kelemahan model pembelajaran free inquiry adalah kurang memungkinkan topik yang dipilih oleh siswa di luar konteks kurikulum (Suryobroto, 2009). Mengingat kelemahan masingmasing model pembelajaran free inquiry dan guided inquiry tersebut, maka peneliti memilih model pembelajaran modified inquiry.

Menurut Sund and Thorbridge (1973) model pembelajaran modified inquiry mempunyai arti modifikasi antara free inquiry dan guided inquiry. Model pembelajaran modified inquiry adalah model pembelajaran dengan cara guru memberi masalah, meminta siswa untuk melaksanakan penyelidikan, dan guru berperan sebagai narasumber. Perbedaan antara ketiganya terletak pada peranan guru dan siswa dalam proses belajar mengajar.

Peranan guru dan siswa pada saat proses kegiatan belajar mengajar diperjelas dengan menggunakan serangkaian sintaks model pembelajaran. National Science Education Standards (NSES) mengungkapkan sintaks yang sangat jelas pada model pembelajaran inkuiri yang dimulai dengan pengungkapan fenomena oleh guru. Mengacu pada sebuah fenomena tersebut, maka timbulah sebuah masalah, dengan demikian diharapkan siswa dapat membuat pertanyaan penelitian, memberikan jawaban sementara terhadap pertanyaan penelitian, melaksanakan penelitian, menganalisis data yang diperoleh dan membuat simpulannya. Sintaks dalam model pembelajaran inkuiri yang dikemukakan oleh NSES sejalan dengan model pembelajaran modified inquiry yang dikemukan oleh Brown et al. (dalam Opara and Oguzor, 2011).
Proses pembelajaran dengan menggunakan model pembelajaran modified inquiry dilanjutkan dengan evaluasi pemahaman konsep yang diadopsi dari Dhindsa dan Treagust (2009), Barke et al. (2009) dan Barke (2012). Evaluasi pemahaman diharapkan dapat mengidentifikasi keberadaan miskonsepsi siswa pada konsep reaksi redoks, sehingga peneliti menggunakan three-tier diagnostic test yang dikembangkan pertama kali oleh Eryilmaz dan Sumery pada tahun 2002. Threetier diagnostic test merupakan suatu instrumen yang khusus untuk mengidentifikasi miskonsepsi siswa, sebab selain siswa menjawab soal yang telah dibuat, siswa juga harus memberikan alasan yang menjelaskan atas jawaban yang telah dipilihnya, serta keyakinan siswa atas jawaban dan alasan yang telah dipilihnya. Alasan yang diberikan siswa dapat memberikan gambaran pada guru tentang miskonsepsi yang dialami siswa (Arslan et al., 2012).

Berdasarkan uraian kelebihan model pembelajaran modified inquiry tersebut, maka peneliti melaksanakan penelitian tentang prevensi miskonsepsi siswa pada konsep reaksi redoks melalui model pembelajaran modified inquiry.

\section{METODE PENELITIAN}

Jenis penelitian yang digunakan adalah praeksperimental, yaitu eksperimen yang dilakukan hanya pada satu kelompok saja, tanpa adanya kelompok pembanding. Desain penelitian ini menggunakan rancangan One Group Pretest-Posttest Design. Sasaran penelitian adalah siswa kelas siswa kelas X IPA 3 dengan replikasi tindakan diberlakukan terhadap siswa yang duduk di kelas X IPA 5, dan X IPA 7 adalah populasi lain yang merupakan sumber data yang digunakan untuk memverifikasi fakta yang diperoleh dari fakta yang diperoleh dari kelas pertama (X IPA 3). Seluruh (total) siswa yang ada di kelas-kelas itu diposisikan sebagai sampel penelitian.

Teknik pengumpulan data yang dilakukan dalam penelitian ini, antara lain: 1) Observasi dan dokumentasi untuk memperoleh data penelitian selama proses pembelajaran berlangsung yang dilakukan oleh tiga orang pengamat yang sudah dilatih dalam menggunakan lembar pengamatan dengan benar, 2) Tes pemahaman konsep berupa three-tier diagnostic test yang diadopsi dari Arslan et al. (2012) dengan kriteria sesuai pada Tabel 1, dan 3) Angket yang terdiri dari dua jenis, yaitu angket faktor penyebab miskonsepsi, dan angket penilaian diri untuk mendapatkan data mengenai kompotensi inti sikap spiritual masing-masing siswa.

Tabel 1 Kriteria Pengelompokan Konsepsi Siswa Berdasarkan Three-tier Diagnostic Test 


\begin{tabular}{ccccc}
\hline \multicolumn{2}{c}{ Respon Siswa } & Kelompok Konsepsi & Singkatan \\
\cline { 1 - 1 } Jawaban & Alasan Keyakinan & & \\
benar & benar & yakin & tahu konsep & TK \\
benar & benar & tidak yakin & tidak tahu konsep & TTK \\
benar & salah & tidak yakin & tidak tahu konsep & TTK \\
salah & benar & tidak yakin & tidak tahu konsep & TTK \\
salah & salah & tidak yakin & tidak tahu konsep & TTK \\
salah & benar & yakin & miskonsepsi 1 & MK1 \\
benar & salah & yakin & miskonsepsi 2 & MK2 \\
salah & salah & yakin & miskonsepsi 3 & MK3 \\
\hline
\end{tabular}

(Arslan et al., 2013:1677)

Teknik analisis data yang digunakan adalah data diskrit dianalisis secara deskriptif, sedangkan data ordinal dan interval dianalisis secara inferensial dengan menggunakan Wilcoxon's Signed Rank Test untuk profil prakonsepsi, dan profil konsepsi, serta KruskalWallis Test dan Mann-Whitney Test untuk keterlaksanaan pembelajaran, dan One Sampel T-Test untuk hasil belajar.

\section{HASIL DAN PEMBAHASAN}

\section{A. Profil Prakonsepsi Siswa pada Konsep Reaksi Redoks}

Pada data yang terdapat pada profil prakonsepsi siswa setelah pretest yang disajikan pada Gambar 1, ditemukan persentase siswa TTK yang paling dominan di ketiga kelas, hal ini dimungkinkan sesuai dengan pendapat Hakim et al. (2012) yang menyatakan budaya siswa-siswa Indonesia yang sering menjawab tidak yakin untuk sesuatu yang baru. Kenyataan ini menggambarkan keadaan yang wajar bagi siswa sebelum mengikuti pembelajaran reaksi redoks.

Pada Gambar 1 selain ditemukan TTK, juga ditemukan MK1, MK2, dan MK3. Menurut Ibrahim (2012) miskonsepsi (MK1, MK2, dan MK3) yang terjadi pada siswa adalah sebuah kewajaran, karena pada dasarnya miskonsepsi tersebut adalah sebuah prakonsepsi (konsepsi awal) yang merupakan hasil pemahaman terhadap suatu fenomena alam (dalam hal ini konsep reaksi redoks) sebelum mempelajarinya secara formal di sekolah. Sebagian dari pemahaman tersebut sesuai dengan pemahaman yang dimiliki dan diyakini kebenarannya oleh para ilmuwan (sesuai dengan konsep ilmiah), namun banyak juga diantara pemahaman tersebut yang sama sekali berbeda dengan konsep ilmiah yang diakui kebenarannya. Prakonsepsi pada seseorang akan hilang ketika diberikan pelajaran konsep yang sebenarnya.

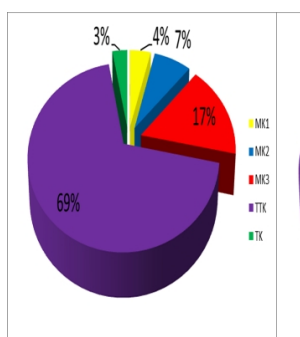

(a)

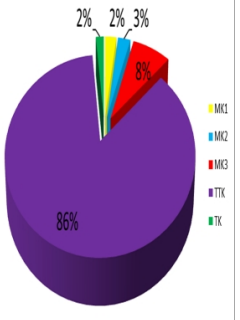

(b)

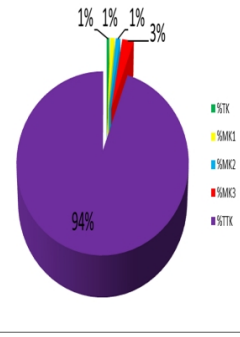

(c)
Gambar 1 Diagram Pastel Prakonsepsi Siswa Kelas

(a) X IPA 3, (b) X IPA 5, dan (c) X IPA 7

Suatu prakonsepsi dapat memicu terjadinya miskonsepsi, sebab apabila suatu prakonsepsi tidak mudah berubah, dan siswa yang memiliki prakonsepsi tersebut selalu kembali pada prakonsepsinya sendiri, meskipun telah diperkenalkan dengan konsep yang benar, maka dapat disimpulkan siswa tersebut mengalami miskonsepsi. Mengingat prakonsepsi merupakan hasil pemahaman terhadap suatu fenomena alam, sehingga dalam profil konsepsi hasil pretest belum tepat apabila siswa dikatakan mengalami miskonsepsi, namun lebih tepatnya adalah alternative conceptions (Horton, 2004). Pendapat ini sesuai dengan pendapat Piaget (dalam Suparno, 2001), yang menyatakan setiap siswa mempunyai struktur pengetahuan awal (skema), walaupun terkadang skema tersebut tidak cocok untuk tahap pemikiran pakar. Skema siswa tersebut tidak dapat dikatakan salah karena skema tersebut merupakan pemahaman akan suatu kejadian sesuai dengan perkembangan pemikirannya.

\section{B. Keterlaksanaan Sintaks Prevensi Miskonsepsi dengan Menggunakan Model Pembelajaran Modified Inquiry}

Sesuai dengan nasehat Gagne et al. (1988) dalam teori learning hierarchi, guru sebelum masuk dalam proses belajar-mengajar sebaiknya mengetahui kemampuan siswa dalam konsep prasyarat. Kemampuan prasyarat tersebut dapat diketahui oleh guru dengan cara terlebih dahulu melaksanakan tes prasyarat, dengan menggunakan three-tier diagnostic test pada kemampuan yang mengambil jenis-jenis miskonsepsi yang ditemukan Horton (2004) dan Dhindsa dan Treagust (2009). Mengingat tes prasyarat merupakan tes yang berfungsi untuk mengetahui apakah siswa telah memiliki pengetahuan dasar yang diperlukan untuk dapat mengikuti pelajaran berikutnya, maka tes prasyarat tersebut harus diberikan pada awal serangkaian pelajaran (Ischak dan Warji, 1987). Konsep-konsep prasyarat untuk belajar konsep reaksi redoks menurut Sukarmin (2004) adalah struktur atom, sistem periodik unsur dan ikatan kimia.

Hasil three-tier diagnostic test pada konsep prasyarat di ketiga kelas adalah persentase siswa TK 
mendominasi pada ketiga konsep prasyarat, meskipun masih terdapat siswa MK pada konsep struktur atom, sistem periodik unsur dan ikatan kimia. Berdasarkan kenyataan tersebut, peneliti berusaha untuk meluruskan konsep prasyarat siswa melalui kegiatan pendahuluan pada sintaks yang terskenariokan dalam RPP, seperti yang disarankan oleh Gagne et al. (1988) tentang sebuah solusi alternatif untuk belajar prasyarat adalah dengan cara review.

Piaget (dalam Suparno, 2001) membedakan pengetahuan menjadi tiga macam, yaitu 1) pengetahuan fisis (physical experience), 2) pengetahuan matematis-logis (logico-mathematical knowledge), dan 3) pengetahuan sosial (social knowledge). Mengadopsi dari pernyataan Piaget (dalam Suparno, 2001) yang menyatakan pengetahuan yang akurat tidak dapat diturunkan langsung dari membaca atau dari mendengarkan guru berbicara, serta pengetahuan fisis, matematis-logis, dan sosial diperoleh langsung dari konstruksi siswa sendiri, maka pada peneliti menggunakan model pembelajaran modified inquiry secara berkelompok.

Pembelajaran secara berkelompok memiliki efek positif pada minat siswa, sikap bahkan prestasi dalam bidang sains, sebab siswa yang kurang mampu dapat memiliki kesempatan mencari bantuan temannya dalam menemukan konsep (Opara and Oguzor, 2011). Pendapat ini sesuai dengan Suparno (1997) yang menyatakan pembelajaran secara berkelompok dapat membantu siswa dalam mengkonstruksi pengetahuannya. Kedua pendapat tersebut, juga sesuai dengan pendapat Saleh (2012) yang menyatakan dalam pembelajaran secara berkelompok memungkinkan siswa untuk berinteraksi dengan teman sebayanya dalam mencapai tujuan. Kerja kelompok dapat juga bermanfaat untuk mengatasi atau mengurangi kefakuman, karena siswa yang mampu diharapkan dapat membimbing temannya yang kurang mampu.

Selain dapat meningkatkan kompetensi inti pengetahuan, pembelajaran modified inquiry secara berkelompok diharapkan juga meningkatkan salah satu kompetensi inti sikap sosial yaitu demokratis, sebagaimana pernyataan Piaget (dalam Suparno, 2001) yaitu belajar bersama memungkinkan sikap kritis dan saling menukarkan perbedaan akan menantang siswa untuk semakin mengoreksi dan mengembangkan pengetahuan yang telah dibentuknya.

Uraian tersebut didukung oleh hasil penilaian ketiga pengamat yang menyatakan sintaks pembelajaran modified inquiry telah berkualifikasi sangat baik pada kedua pertemuan di ketiga kelas, dan hasil analisis terhadap skor dari ketiga pengamat dengan menggunakan Kruskal-Wallis Test memperoleh p-value lebih besar daripada nilai kritik baik pada pertemuan I, maupun pertemuan II di ketiga kelas, sehingga dapat disimpulkan bahwa pengamat mempunyai pandangan yang sama mengenai keterlaksanaan pembelajaran modified inquiry.

Kenyataan ini juga didukung oleh hasil MannWhitney Test yang menghasilkan $p$-value lebih besar dari nilai kritik, sehingga dapat disimpulkan bahwa guru mampu mempertahankan kualitas pengajaran dengan menggunakan model modified inquiry baik pada pertemuan I maupun pertemuan II di ketiga kelas. Berdasarkan uraian keterlaksanaan sintaks dalam pembelajaran pertemuan I dan II dapat disimpulkan bahwa semua sintaks model pembelajaran modified inquiry yang mengadopsi dari National Science Education Standart telah terlaksana dengan sangat baik di ketiga kelas.

\section{Profil Konsepsi Siswa Sesudah Pembelajaran dengan Menggunakan Model Modified Inquiry}

Profil konsepsi siswa yang dihasilkan setelah pembelajaran modified inquiry disajikan pada Gambar 2. Pada Gambar 2 memberikan hasil bahwa secara klasikal siswa telah memahami konsep reaksi redoks mencapai $60 \%$ di kelas X IPA 3, 48\% di kelas X IPA 5, dan $64 \%$ di kelas X IPA 3. Penjelasan yang dapat diberikan pada kenyataan ini adalah bermula dari model modified inquiry yang diterapkan. Siswa dilibatkan secara aktif (student centered) di dalam model pembelajaran modified inquiry, dengan cara menuntut siswa untuk menggali informasi untuk memahami suatu konsep melalui sebuah fenomena kehidupan sehari-hari yang sesuai dengan konsep yang dipelajari, sehingga fenomena atau gejala-gejala fisis tersebut dapat dijelaskan secara konseptual. Pada proses tersebut siswa belajar mengalami dan mengaitkan pengetahuan sebelumnya kedalam materi yang sedang dipelajari, serta siswa mengkonstruksi sendiri pemahamannya. Berdasarkan uraian tersebut, maka dapat diprediksi bahwa peningkatan yang tajam pada siswa TK, dikarenakan siswa tersebut telah berhasil mengkonstruksi sendiri pengetahuan fisis, dan pengetahuan logiko-matematisnya. Pengetahuan tersebut dapat dikonstruksi siswa dengan cara mengaitkan pengetahuan prasyarat dengan konsep reaksi redoks atau siswa berhasil melaksanakan proses asimilasi dalam skemanya (Suparno, 2001).

Kenyataan masih ditemukan adanya siswa TTK pada konsep reaksi redoks, dimungkinkan karena selain melibatkan konstruksi pengetahuan fisis, dalam konsep ini juga harus melibatkan konstruksi pengetahuan matematis-logis. Menurut Piaget dalam The Psychology of Inteligence (dalam Suparno, 2001) menyatakan bahwa struktur matematis-logis, bukanlah sesuatu yang menetap pada siswa, melainkan sesuatu yang terbentuk 
secara perlahan-lahan dalam perkembangannya. Pada siswa yang masih TTK dimungkinkan konstruksi pengetahuan siswa tersebut belum tercapai atau tidak mempunyai waktu yang cukup pada proses pengkonstruksian tersebut. Pendapat Piaget ini sesuai dengan pendapat Opara and Oguzor (2011), yang menyatakan pada dasarnya pembelajaran modified inquiry memerlukan waktu yang lama. (a)

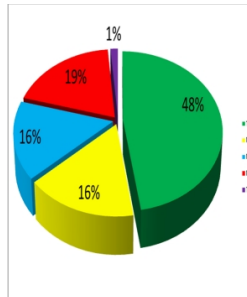

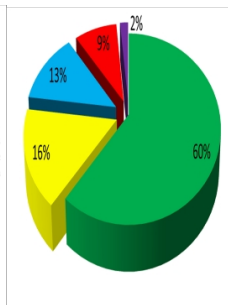

(b)

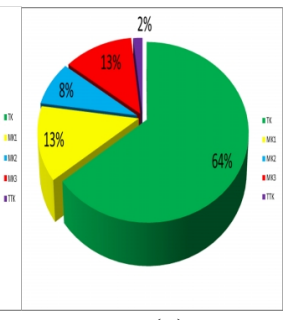

(c)
Gambar 2 Diagram Pastel Konsepsi Siswa Sebelum Pembelajaran Remedial di Kelas (a) X IPA (b) X IPA 5, dan (c) X IPA 7

Selain faktor waktu, ada alasan lain yang mendasari masih ditemukannya miskonsepsi baik MK1, MK2, maupun MK3. Kemungkinan besar siswa tersebut salah mengkonstruksi pemahamannya yang bermula dari miskonsepsi pada konsep prasyarat, atau alternative conceptions yang kembali meskipun sudah diberikan pengetahuan yang benar. Sesuai dengan pendapat Fowler (dalam Suparno, 2005) yang menjelaskan bahwa penggunaan konsep yang salah pada prasyarat, akan menyebabkan terjadinya kekacauan konsep-konsep dan hubungan hierarkis konsep-konsep yang tidak benar antara konsep prasyarat dengan konsep reaksi redoks, sehingga mengakibatkan siswa mengalami miskonsepsi yang berkelanjutan.

Kenyataan tersebut sesuai dengan pendapat Horton (2004) yang menyatakan apabila siswa membangun pemahaman baru yang keluar dari konsepkonsep yang sudah mereka miliki (miskonsepsi pada konsep prasyarat dan prakonsepsi yang telah dimilikinya), maka tidak dapat dihindari bahwa siswa akan mengalami miskonsepsi pada bagian tersebut. Akibat miskonsepsi pada konsep prasyarat dan prakonsepsi yang kembali lagi, maka pengalaman baru diinterpretasikan siswa melalui pemahaman yang salah, sehingga mengganggu siswa menangkap pengalaman baru (Barke et al.,2009). Kenyataan ini dimungkinkan pula siswa belum sempurna dalam melaksanakan proses akomodasi dalam skemanya. Pernyataan tersebut sesuai dengan teori Piaget (dalam Suparno, 2001) yang menyatakan apabila skema yang lama tidak cocok lagi untuk berhadapan dengan pengalaman yang baru, maka skema yang lama tersebut diubah sampai ada kesetimbangan lagi dengan proses akomodasi.
Selain kegagalan dalam proses akomodasi, kenyataan tersebut juga dimungkinkan siswa tidak mengkonstruksi pengetahuan secara utuh, seperti yang diungkapkan oleh Suparno (2001). Kemungkinan lain adalah alternative conceptions siswa yang masih melekat. Alternative conceptions tersebut tidak berubah, dan siswa selalu kembali meskipun telah diperkenalkan dengan konsep yang benar, sehingga siswa mengalami miskonsepsi (Ibrahim, 2012). Barke et al. (2009) juga berpendapat miskonsepsi dapat terjadi pada beberapa konsep sangat sulit untuk dipahami yang disebabkan oleh sifat dari konsep tersebut yaitu abstrak, kontra-intuitif atau kompleks, sehingga pemahaman terhadap konsep tersebut tidak utuh, sebab Chiu (2005), Horton (2004), Reid (2008), Barke (2012), dan AlBalushi et al. (2012) mengungkapkan konsep reaksi redoks merupakan konsep yang sulit.

Keberhasilan sebuah model pembelajaran dalam memprevensi miskonsepsi perlu dibandingkan dengan hasil prevensi miskonsepsi dari penelitian lainnya. Penelitian Miller et al. (dalam Dazhi and Inanc, 2013) dalam memprevensi miskonsepsi siswa dengan menggunakan inquiry-based approach pada konsep transfer energi, memberikan simpulan yang tidak efektif. Penelitian Bartlow (2011) dalam memprevensi miskonsepsi siswa pada mata pelajaran kimia selama 3 semester dengan menggunakan Process Oriented Guided Inquiry Learning, hanya memperoleh hasil sebesar 14,8\%. Berdasarkan ulasan tersebut maka dapat disimpulkan bahwa model modified inquiry telah berhasil memprevensi miskonsepsi siswa pada konsep reaksi redoks.

\section{Faktor Penyebab Miskonsepsi Siswa pada Konsep Reaksi Redoks}

Berdasarkan hasil angket, akumulasi sumber penyebab miskonsepsi yang terbesar adalah prakonsepsi siswa. Prakonsepsi siswa terbesar terjadi di kelas X IPA 5, hal ini sesuai dengan persentase pemahaman konsep siswa kelas X IPA 5 paling kecil dibandingkan kelas X IPA 6, dan X IPA 7. Kurang maksimalnya persentase pemahaman konsep siswa bukan disebabkan oleh pembelajaran dengan model modified inquiry yang dilaksanakan guru.

Kurang maksimalnya model pembelajaran modified inquiry dalam memprevensi miskonsepsi siswa disebabkan oleh faktor lain, sebab pada dasarnya pembelajaran yang konsisten menggunakan inkuiri cenderung mampu mengubah konsep lama yang miskonsepsi dengan konsep baru (Horton, 2004). Pernyataan ini juga didukung hasil penilaian ketiga pengamat, yang menggambarkan model pembelajaran modified inquiry sudah terlaksana dengan kualifikasi sangat baik. Keberhasilan model modified inquiry juga 
tampak pada hasil learning task (analisis deskritif) yang berkualifikasi sangat baik.

Simpulan dari uraian sumber penyebab miskonsepsi yang mendominasi pada penelitian ini adalah prakonsepsi (konsepsi awal) siswa. Hasil penelitian ini sejalan dengan pendapat Barke et al. (2009) bahwa miskonsepsi bersifat resisten atau sulit diubah dan cenderung bertahan. Horton (2004) juga berpendapat bahwa miskonsepsi memiliki potensi untuk memblokir atau menghalangi kemajuan lebih lanjut (Horton, 2004).

\section{E. Perubahan Hasil Belajar Siswa Sesudah Pembelajaran dengan Menggunakan Model Modified Inquiry}

Perubahan hasil belajar siswa setelah prevensi miskonsepsi siswa pada konsep reaksi redoks dengan menggunakan modified inquiry disimpulkan dengan dua teknik analisis, yaitu teknik analisis deskriptif dan teknik analisis inferensial. Kedua teknik analisis hanya memperhitungkan skor jawaban benar tanpa tier-3 antara sesudah dan sebelum pembelajaran.

Analisis deskriptif lebih ditujukan untuk menguji pencapaian target KKM siswa, sedangkan analisis inferensial lebih ditujukan untuk menguji efektivitas model modified inquiry dalam meningkatkan pemahaman siswa. Secara deskriptif dengan KKM $80 \%$, maka pada kelas X IPA 3 hanya 18 siswa yang tuntas (46\%), pada kelas X IPA 5 hanya 8 siswa yang tuntas $(24 \%)$, dan pada kelas X IPA 7 hanya 17 siswa yang tuntas $(42 \%)$.

Keadaan yang berbeda-beda pada setiap kelas tersebut, sesuai dengan hasil penelitian John Carol (dalam Arifin, 1995) yang menemukan bahwa siswa memiliki kecepatan yang berbeda dalam memahami suatu konsep, siswa dapat mencapai tujuan belajar dengan baik apabila diberi waktu yang sesuai kebutuhannya. Kecepatan yang berbeda dalam memahami konsep reaksi redoks, membuat siswa di kelas X IPA 5 mempunyai persentase pemahaman konsep yang paling rendah dibandingkan dengan siswa di kelas X IPA 3, maupun kelas X IPA 7.

Selain analisis deskriptif, juga dilaksanakan analisis inferensial untuk menguji efektivitas model modified inquiry dalam meningkatkan pemahaman siswa pada konsep reaksi redoks. Analisis inferensial diputuskan menggunakan One Sampel T-Test, sebab data yang diperoleh adalah berupa data interval dan populasi berdistribusi normal (Sugiyono, 2008). Hasil One Sampel T-Test tersebut adalah ketiga kelas mempunyai $t_{\text {hitung }}>\mathrm{t}_{\text {tabel }}$ dengan derajat kepercayaan 95\% seperti yang tercantum pada Tabel 2 .
Tabel 2 Hasil One Sampel T-Test Terhadap Hasil Belajar

Siswa Pada Konsep Reaksi Redoks

\begin{tabular}{lccc}
\hline & Kelas X IPA 3 & Kelas X IPA 5 & Kelas X IPA 7 \\
\hline${ }^{\mathrm{t}}$ hitung & 22,537 & 15,062 & 18,276 \\
${ }^{\mathrm{t}}$ tabel & 1,701 & 1,699 & 1,697 \\
p-value & 0,000 & 0,000 & 0,000
\end{tabular}

Simpulan yang diperoleh dari hasil analisis inferensial adalah model modified inqury telah efektif meningkatkan pemahaman siswa pada konsep reaksi redoks secara signifikan. Hal ini tidak terlepas dari keterlaksanaan model pembelajaran modified inquiry pada kedua pertemuan yang mendapatkan nilai dengan kualifikasi sangat baik, sehingga dapat meningkatkan pemahaman konsep reaksi redoks pada siswa. Kenyataan ini sesuai dengan Arends (2012) bahwa sintaks dalam sebuah model pembelajaran harus dilaksanakan dengan sangat baik oleh guru untuk menjamin kualitas proses pembelajaran. Kenyataan ini juga didukung oleh penelitian Widowati (2008), Khanafiah dan Rusilowati (2010), dan Widodo (2012) yang menyatakan model pembelajaran modified inquiry secara signifikan efektif meningkatkan hasil belajar siswa.

Berdasarkan hasil kedua analisis tersebut, maka dapat disimpulkan pembelajaran menggunakan model modified inquiry terbukti mampu meningkatkan pemahaman siswa terhadap konsep reaksi redoks secara signifikan walaupun belum mampu mencapai target KKM, sehingga sangat diperlukan pembelajaran remedial.

\section{SIMPULAN}

Tindakan prevensi miskonsepsi siswa pada konsep reaksi redoks di SMA Negeri 1 Sidoarjo dengan menggunakan model pembelajaran modified inquiry menghasilkan simpulan tindakan prevensi yang dilakukan sudah berhasil membentuk siswa tahu konsep sebanyak 60\% (X IPA 3), 48\% (X IPA 5), dan 64\% (X IPA 7).

\section{DAFTAR PUSTAKA}

Al-Balushi, S.M., Ambusaidi, A.K., Al-Shuaili, A.H., and Taylor, N. 2012. "Omani Twelefth Grade Students' Most Common Misconceptions in Chemistry". Muscat: Journal of Science Education International, 23(3), 221-240.

Arends, R.I. 2012. Learning to Teach $9^{\text {st }}$ Edition. New York: McGraw-Hill.

Arslan, H.O., Cigdemoglu, C., and Moseley, C. 2012. "A Three-Tier Diagnostic Test to Assess PreServiceTeachers' Misconceptions about Global 
Warming, Greenhouse Effect, Ozone Layer Depletion, andAcid Rain". San Antonio: Education International Journal of Science Education, 34(11),1 667-1686.

Arifin, M. 1995. Pengembangan Program Pengajaran Bidang Studi Kimia. Surabaya: Airlangga University Press.

Barke, H.D., Al Hazari, and Yitbarek, S. 2009. Misconceptions in Chemistry. Springer Link.

Barke, H.D. 2012. "Two Ideas of The Redox Reaction: Misconceptions and Their Challenge in Chemistry Education". Atlanta: Atlanta Journal Chemistry Education, 2(2), 32-50.

Barthlow, M.J. 2011. "The Effectiveness of Process Oriented Guided Inquiry Learning to Reduce Alternate Conceptions in Secondary". Liberty University: Chemistry Disertation.

Chiu, M.H. 2005. "A National Survey of Student' Conceptions in Chemistry in Taiwan". Istanbul: Journal of Chemical Education International, $6(1), 1-8$.

Dazhi, Y., and Inanc, S. 2013. "The Search for Strategies to Prevent Persistent Miconceptions". Atlanta: $120^{\text {th }}$ ASEE Annual Conference \& Eksposition.

Dhindsa, H.S., and Treagust, D.F. 2009. "Conceptual Understanding of Bruneian Tertiary Students: Chemical Bonding and Structure". Universiti Brunei Darussalam: Brunei International Journal of Science and Mathematic Education, 1(1), 3351.

Gagne, R.M., Briggs, L.J., and Wager, W.W. 1988. Principle of Instructional Design. Florida: Holt, Rinehart and Winston, Inc.

Hakim, A., Liliasari., and Kadarohman. A. 2012. "Student Concep Understanding of Natural Products Chemistry in Primary and Secondary Metabolis Using the Data Collecting Technique of Modified CRI". Mataram: International Online Journal of Educational Sciences.

Horton, C. 2004. "Student Alternative Conception in Chemistry". California: California Journal of Science Education, 7(2), 1-78.

Ibrahim, M. 2012. Konsep Miskonsepsi dan Cara Pembelajarannya. Surabaya: Unesa University Press.

Ischak, S.W., dan Warji. R. 1998. Program Remedial dalam Proses Belajar Mengajar. Yogyakarta: Liberty.

Kementerian Pendidikan dan Kebudayaan. 2013. Kurikulum 2013. Jakarta: Kementrian Pendidikan dan Kebudayaan.

Khanafiyah, S., dan Rusilowati, A. 2010. "Penerapan Pendekatan Modified Free Inquiry sebagai Upaya
Meningkatkan Kreativitas Mahasiswa Calon Guru dalam Mengembangkan Jenis Eksperimen dan Pemahaman terhadap Materi Fisika". Semarang: Jurnal Universitas Negeri Semarang (Edisi Khusus), 13(2), E7- E14.

Opara, J.A., and Oguzor, N.S. 2011. "Inquiry Instructional Method and the Scholl Science Curriculum". Nigeria: Current Research Journal of Social Science 3(3):188-198

Reid, N. 2008. "A Scientific Approach to The Teaching of Chemistry". Glasgow: Journal of The Royal Society of Chemistry, 9, 51-59.

Saleh, M. 2012. "Pembelajaran Kooperatif dengan Pendekatan Matematika Realistic. Banda Aceh: Jurnal Pendidikan Serambi Ilmu, 13(2), 51-59.

Sugiyono. 2008. Metode Penelitian Pendidikan. Pendekatan Kuantitatif, Kualitatif, dan $R \& D$. Bandung: Alfabeta

Sukarmin.2004. Reaksi Oksidasi Reduksi. Jakarta: Departemen Pendidikan Nasional.

Sund, Robert B., and Leslie W. Trowbridge. 1973. Teaching Science by Inquiry in The Secondary School. Colombus: Merrill.

Suparno, P. 2001. Teori Perkembangan Kognitif Jean Piaget. Yogyakarta: Kanisius.

Suparno, P. 2005. Miskonsepsi dan Perubahan Konsep Pendidikan Fisika. Jakarta: Gramedia Widiasarana Indonesia.

Wahyuningrum, S., dan Suyono. 2013. "Pola Pergeseran Konsepsi Siswa pada Struktur Atom setelah Pembelajaran dengan Strategi POGIL". Surabaya:UNESA Journal of Chemical Education, 2(1), 43-50.

Widowati, A. 2008. "Impoving The divergent Thinking Skill Using The Modified Free Inquiry Approach to Teaching Science". Yogyakarta: Jurnal Penelitian dan Evaluasi Pendidikan, Nomor 1, Tahun XI, 118-127.

Yunianingsih, W., dan Suyono. 2013. "Tingkat Keterampilan Berpikir Siswa Saling Bergantung (Dependen) dengan Tingkat Penguasaan Konsep Siswa". Surabaya: UNESA Journal of Chemical Education, 2(1), $1-10$. 